Maria Alejandra Fajardo-Mejía', Juan Gonzalo Morales-Osorio', Guillermo Antonio Correa-Londoño', Juan Diego León-Peláez'

\title{
EFFECT OF PLANT EXTRACTS AND GROWTH SUBSTRATES ON CONTROLLING DAMPING-OFF IN PINUS TECUNUMANII SEEDLINGS
}

Keywords:

Pine bark

Rice hull

Coconut husk

Sandy soil

Pine seedling disease

Histórico:

Recebido 18/03/2016

Aceito 02/09/2016

Palavras chave:

Casca de pinheiro

Casca de arroz

Casca de coco

Solo arenoso

Doença de mudas de Pinus

Correspondência: jdleon@unal.edu.co

DOI:
ABSTRACT: Damping-off is considered one of the most limiting phytosanitary problems in conifer seedling production because it may cause massive damage or total plant death in short time periods. This pathology is caused by a complex of microorganisms, the most common of which are Fusarium spp. and Rhizoctonia spp. This study evaluated the effect of growth substrates and plant extracts at different concentrations on germination and incidence of disease in Pinus tecunumanii plants. The plants were inoculated with the damping-off pathogen Fusarium oxysporum and treatments were applied in a completely randomized design with a factorial arrangement of $4 \times 2 \times 3$. This corresponded to four substrates (pine bark, rice hull, coconut husk and sandy soil (4:I)); two plant extracts (Matricaria chamomilla and Datura stramonium), and three concentrations of each extract (Control concentration: 0\%, Concentration I: $50 \%$ and Concentration 2: Undiluted). Each treatment had three repetitions, with 25 plants per repetition. The growth substrates affected germination; the most effective of these were sandy soil (4:I) and pine bark, with $90 \%$ and $92 \%$ germination at day 20 , respectively. No significant difference was observed between the germination obtained with these substrates and that obtained with coconut husk after day 19. Meanwhile, all of the extracts had a significant effect on controlling the disease when they were combined with the substrates, with the exception of coconut husk. With this last substrate the incidence of disease was lower than $4 \%$ without the application of plant extracts; this indicates that coconut husk discourages the development of the disease on its own.

\section{EFEITO DE EXTRATOS VEgetaIS E SUBStRATOS DE PLANTIO NO CONTROLE DO TOMBAMENTO EM MUDAS DE Pinus tecunumanii}

Tombamento é considerado um dos mais limitantes problemas fitossanitários na produção de mudas de coníferas, pois pode causar grandes danos ou morte total da planta em curtos períodos de tempo. Esta patologia é causada por um complexo de microrganismos, os mais comuns são Fusarium spp. e Rhizoctonia spp. Este estudo avaliou o efeito de substratos de plantio e extratos vegetais em diferentes concentrações sobre a germinação e incidência da doença em mudas de Pinus tecunumanii. As mudas foram inoculadas com o fungo causador de tombamento Fusarium oxysporum e os tratamentos foram aplicados de forma totalmente casualizados com arranjo fatorial $4 \times 2 \times 3$. O experimento foi composto por quatro substratos (casca de pinheiro, casca de arroz, casca de coco e solo arenoso (4:I)); dois extratos de plantas (Matricaria chamomilla e Datura stramonium) e três concentrações de cada extrato (Concentração testemunha: 0\%, Concentração I: 50\% e Concentração 2: não diluído). Cada tratamento teve três repetições, com 25 plantas por repetição. Os substratos de plantio afetaram a germinação; o mais eficaz destes foi o solo arenoso (4:I) e casca de pinheiro, com $90 \%$ e $92 \%$ de germinação no dia 20 , respectivamente. Não foi observada diferença significativa entre a germinação obtida com estes substratos e a obtida com casca de coco após o dia 19. Entretanto, todos os extratos tiveram efeito significativo sobre o controle da doença quando eram combinados com os substratos, com a excepção da casca de coco. Com este último substrato a incidência de doença era inferior a $4 \%$, sem a aplicação de extratos de plantas; isto indica que casca de coco inibe o desenvolvimento da doença por conta própria.

' Universidad Nacional de Colombia - Medellín, Colombia 


\section{INTRODUCTION}

Colombia has 24 million hectares of land suitable for the establishment of commercial forest plantations. However, only 450,000 ha have been cultivated, which generated a deficit in the commercial timber supply (UPTRA, 20I5). The species with the greatest potential include Pinus tecunumanii, which has shown high performance in terms of supplying both the domestic and international industries (e.g. pulp, sawdust, construction, boards). There has been an average annual increase of $30-40 \mathrm{~m}^{3} / \mathrm{ha} /$ year in plantations of this species in Colombia over the past 16 years, with internal rates of return above $16 \%$. These figures indicate its potential compared to other commercial species planted in the country (PROEXPORT Colombia, 20I0).

The initial survival and growth of trees used in reforestation depends primarily on the quality of the seedlings produced in the nursery (Cetina et al., 2002). The disease known as damping-off represents the most serious phytosanitary problem to the largescale production of seedlings, since it can cause up to $100 \%$ losses in production and can progress as fast as in 24 hours (Kacprzak et al., 200 I; Martín-Pinto et al., 2008). This pathology, which is common in the seeds and seedlings of many forest and crop species, is caused by a complex of microorganisms including oomycetes and fungi, which are favored by high moisture and water logging. The most common genera associated with the pathology are Phytophthora, Pythium, Fusarium and Rhizoctonia (Camporota and Perrin, 1998; Gordon et al., 2015). Some strains of the Fusarium genus have been reported as causal agents of damping-off in seedlings of the Pinus genus, including $P$. nigra and $P$. pinea (MartínPinto et al., 2006; Machón et al., 2009).

Phytosanitary analysis have shown that the disease inoculum can have various sources of origin, such as seeds, irrigation water and the substrate used, which can contain pathogenic fungi such as F. oxysporum, F. solani and Alternaria alternata (Soldevilla, 1995).

The complexity of the disease and the variety of agents that can cause it has led to the indiscriminate use of fungicides for its control (e.g. dazomet, metam sodium, vapan, formalin and methyl bromide, among others). These usually do not have the desired effectiveness and their high toxicity damages the environment and affects human and animal health (Rauf, 2000; Torres and Capote, 2004). Additionally, the continual or inappropriate use of some of these products leads to a decrease in their effectiveness and resistance to the pathogens they are meant to control, usually exacerbating the problem (Rauf, 2000).

Studies looking for alternative options for controlling damping-off have focused on the antifungal properties of plant extracts which contain compounds synthesized in their secondary metabolism. Essential oils from Matricaria recutita and $M$. chamomilla have been used to inhibit the growth of saprophytic and opportunistic fungi like Aspergillus flavus, A. fumigatus, A. Niger, Trichoderma harzianum and Fusarium oxysporum (Tolouee et al., 2010; Jamalian et al., 2012). Similarly, extracts from the species Datura stramonium, Calotropis gigantea, and Azadirachta indica (neem) have been used to control Fusarium mangiferae (USHA et al., 2009).

In addition, selection of an appropriate growth substrate represents a key step for the preventive management of diseases, since the physical and chemical properties of substrates have direct effects on disease development or suppression, during the seedling germination and initial stages of plant development (Sáez, 1999; Benítez et al., 2002; Landis and Morgan, 2009).

With the objective of finding alternative and environmentally friendly strategies to control dampingoff in $P$. tecunumanii seedlings, we evaluated the effects of a series of treatments on germination and disease incidence during the nursery stage. These treatments were based on the use of plant extracts from $D$. stramonium and $M$. chamomilla and different growth substrates (coconut husk, pine bark, rice hull and sandy soil).

\section{MATERIALS AND METHODS}

\section{Location}

The study was carried out in a forest nursery located in the municipality of San José del Nus in Antioquia, Colombia, South America (Coordinates 627'31', 65N, $\left.-74^{\circ} 48^{\prime} 54^{\prime \prime}, \mathrm{I} 4 \mathrm{~W}\right)$. The nursery is located at an altitude of 8 I 5 MASL, with an average annual precipitation of 2,620 $\mathrm{mm}$, an average annual temperature of $28-32{ }^{\circ} \mathrm{C}$ and relative humidity of $40-70 \%$.

\section{Inoculum preparation}

The pathogenic fungus used in this study was Fusarium oxysporum (strain 00IF). It was selected because of its high aggressiveness on $P$. tecunumanii seedlings (FAJARDO-MEJÍA et al., 20I5). The fungus was multiplied in Petri dishes, in Potato-Dextrose-Agar (PDA) medium. The strain was incubated at $28^{\circ} \mathrm{C}$ for 14 days. The spore inoculum was prepared by adding sterile distilled water to the petri dishes and mycelium 
scrapings. Afterwards, the spores were quantified in a Neubauer chamber to adjust the concentration to $|x| 0^{6}$ spores $/ \mathrm{ml}$.

\section{Substrate preparation}

Four substrates were tested: I. Coconut husk (granulometry 0-2.5 mm, Sustitutos Ecológicos ${ }^{\circledR}$, Medellín, Colombia); 2. Pine bark (Pinus caribaea) provided by the company Refocosta, Colombia, which was processed in a mill ( $7 \mathrm{~mm}$ sieve) and then composted for approximately 120 days; 3. Substrate prepared by mixing horizon A of a soil from the zone (Typic Hapludox) with sand (4:I); and 4. Rice hull, previously heated on a metal plate to decrease its hydrophobicity. Each substrate was initially moistened to saturation in order to fill the seed trays, which were disinfected by immersion in $1 \%$ sodium hypochlorite for $4 \mathrm{~h}$. Each seed tray had 25 cells with $125 \mathrm{ml}$ capacity each. Each individual cell had a center drainage hole on the bottom and four side-drain holes on the tapered end.

\section{Pathogen inoculation and seed planting}

Pathogen inoculation was performed one day prior to planting the $P$. tecunumanii seeds. $1.5 \mathrm{ml}$ of $F$. oxysporum inoculum $\left(\mid \times 10^{6}\right.$ spores $\left./ \mathrm{ml}\right)$ per sown seed in each tray cell were applied. Seeds of $P$. tecunumanii were provided by INAFOR (National Forest Institute, Nicaragua) and came from Reserva de Recursos Genéticos (Genetic Resources Reserve) of Yucul, Nicaragua. The seeds were previously submerged in distilled water for $12 \mathrm{~h}$ to hydrate them. They were planted one day after the substrate was inoculated with the pathogen. Plants were maintained under nursery conditions at the experimental site.

\section{Plant propagation for extracts}

Chamomile (M. chamomilla) and datura (D. stramonium) were propagated from seeds planted in soil; once germinated, they were kept irrigated at field capacity. To produce the extracts, the aerial part of $M$. chamomilla plants (leaves, flowers and stem) (approximately three months after planting) and just the pre-flowering leaves of D. stramonium plants (approximately four months after planting), were collected.

\section{Ethanolic extract (EE) preparation}

The plant material was harvested and wrapped in newspaper and immediately taken to the laboratory for processing. The material was dried in an oven for 4 days at $37^{\circ} \mathrm{C}$. Afterwards, the samples were pulverized in a mill and then macerated in $96 \%$ ethanol ( $120 \mathrm{~g}$ of plant material in $450 \mathrm{ml}$ of ethanol). The obtained macerate was stored in amber flasks to prevent photo-degradation and then left in agitation for $12 \mathrm{~h}$ at room temperature $\left(\sim 22^{\circ} \mathrm{C}\right)$. After $12 \mathrm{~h}$, the macerate was filtered through four layers of gauze and then distilled in a rotoevaporator BrinkmannMR at $100^{\circ} \mathrm{C}$. On average, 4-5 ml of crude EE was obtained with each extraction, this process was repeated for each plant type until obtaining the amount of volume needed for the application. The EE was stored in amber flasks at $\left(4^{\circ} \mathrm{C}\right)$ until it was applied in the field (MARCANO and HASEGAWA, 2002; FAJARDO-MEJÍA et al., 20I3).

\section{Application of plant extracts to the substrate}

Two applications of each extract $(2 \mathrm{ml})$ were made to the substrates in two different concentrations: crude EE and a $50 \%$ dilution in distilled water. The first application was made two days before planting and the second 12 days afterwards.

\section{Statistical analysis}

The treatments were organized based on a factorial arrangement of $4 \times 2 \times 3$. This corresponded to four substrates (pine bark, rice hull, coconut husk, and sandy soil (4:I)), two plant extracts (Datura stramonium and Matricharia chamomilla) and three concentrations for each extract (control with $0 \%$ extract; concentration I: $50 \%$ EE in distilled water; and concentration 2: undiluted EE). The treatments were assigned to experimental units in a completely randomized design. Each treatment had three repetitions, with 25 P. tecunumanii plants per repetition. Germination (\%) was evaluated as the number of germinated seeds divided by the total number of seeds planted, multiplied by 100 . Disease incidence (\%) was calculated as the number of diseased plants per repetition divided by the total number of plants, multiplied by 100 . To evaluate the effect of the treatments on the disease incidence, an analysis of variance was performed with a significance level of $\alpha=0.05$. Similarly, analysis of repeated measures in time was performed for the variables of Germination and Incidence. This made it possible to identify and compare trends over time of the observed responses to the treatments. This analysis was performed using the MIXED procedure of SAS ${ }^{\circledR}$, version 9.0, based on a first-order autoregressive structure for modeling covariance. Graphics of means were generated based on the adjusted means for the different combinations. The treatments evaluated were Pine bark 
(PB), Coconut husk (CH), Rice hull (RH), Sandy soil (v/v) (4:I) (SS), Datura stramonium extract (D), Matricaria chamomilla extract (M), Concentration I- Plant extract $50 \%$ (I), Concentration 2 - Plant extract non diluted (2), and Control (C).

\section{RESULTS}

\section{Effect of substrates on germination}

Highly significant effect on the germination percentage by the interaction substrate*time was found from the analysis of variance (Table I) $(P=0.000 I)$. The SS and PB substrates exhibited similar patterns over time (Figure I). These registered significantly higher average

TABLE I Parameters estimates of the omnidirectional and cross semivariograms $\mathrm{Vol}=$ volume, $\operatorname{Exp}=$ Exponential. Analysis of variance

\begin{tabular}{|c|c|c|c|}
\hline Effect & D.F & $\begin{array}{c}(\%) \\
\text { Germination } \\
\operatorname{Pr}>\mathrm{F}\end{array}$ & $\begin{array}{c}\%) \\
\text { Incidence } \\
\operatorname{Pr}>\mathrm{F} \\
\end{array}$ \\
\hline Substrate & 3 & $<.0001^{*}$ & $<.0001^{*}$ \\
\hline Extract & 1 & 0.6788 & 0.2762 \\
\hline Substrate ${ }^{\star}$ Extract & 3 & 0.9830 & 0.2643 \\
\hline Concentracion & 2 & 0.8798 & $<.0001$ \\
\hline Substrate ${ }^{*}$ Concentracion & 6 & 0.3598 & $<.0001$ \\
\hline Extract ${ }^{\star}$ Concentracion & 2 & 0.7637 & 0.7026 \\
\hline Substrate* Extract ${ }^{\star}$ Concentracion & 6 & 0.8909 & $<.0001^{*}$ \\
\hline Substrate*Time & 33 & $<.0001^{*}$ & $<.0001^{*}$ \\
\hline Extract ${ }^{\star}$ Time & 11 & 0.9014 & 0.0820 \\
\hline Substrate*Extract* Time & 33 & 0.9997 & 0.5784 \\
\hline Substrate* Concentracion *Time & 66 & 0.7083 & $<.0001^{*}$ \\
\hline Extract ${ }^{*}$ Concentracion ${ }^{*}$ Time & 22 & 0.7484 & 0.5289 \\
\hline $\begin{array}{l}\text { Substrate*Extract* } \\
\text { Concentracion *Time }\end{array}$ & 66 & 0.9917 & 0.3903 \\
\hline
\end{tabular}

The variables shown with * are those with a significant effect.

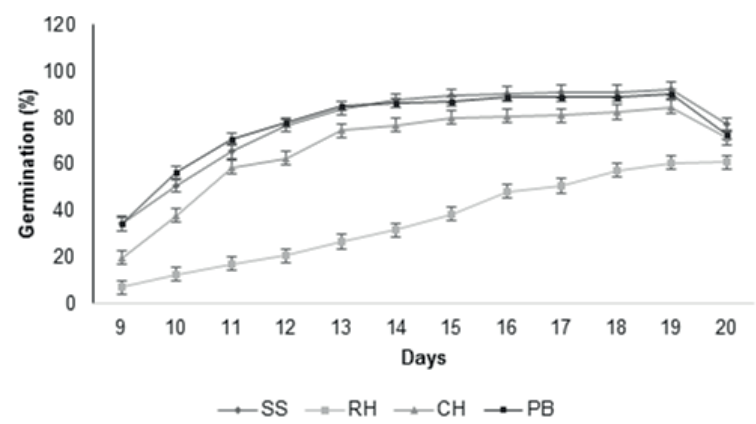

FIGURE I Average germination of Pinus tecunumanii seeds (\%) in different growth substrates over time. SS: sandy soil 4: I, RH: rice hull, $\mathrm{CH}$ : coconut husk and PB: pine bark. Average germination was calculated from 75 seedlings per treatment. germination percentages than the other substrates at all times except after day 19 when Coconut Husk did not differ significantly from the SS and PB substrates. Meanwhile, the average germination percentages for the $\mathrm{RH}$ substrate were significantly lower than those of the other substrates at any time $(\mathrm{P} \leq 0.0 \mathrm{I})$, with values of $61 \%$ registered at day 20 .

\section{Effect of extracts on damping-off incidence}

Other important significant effect identified was the interaction between the factors Substrate, Plant extract and Concentration ( $\mathrm{P}=0.000 \mathrm{I}$ ) (Table I). Figure 2 illustrates that when the PB or SS substrates were used, the application of either of the two extracts in any concentration significantly decreased the disease incidence. However, when SS was used, the extract concentration I of datura was not as effective as concentration 2 of datura or extract concentration I of chamomile.

When the $\mathrm{RH}$ substrate was used with any concentration of $D$. stramonium or with extract concentration 2 of $M$. chamomilla, the disease incidence was significantly lower. Concentration I of the $M$. chamomilla extract did not produce a significant difference compared to the control without extract.

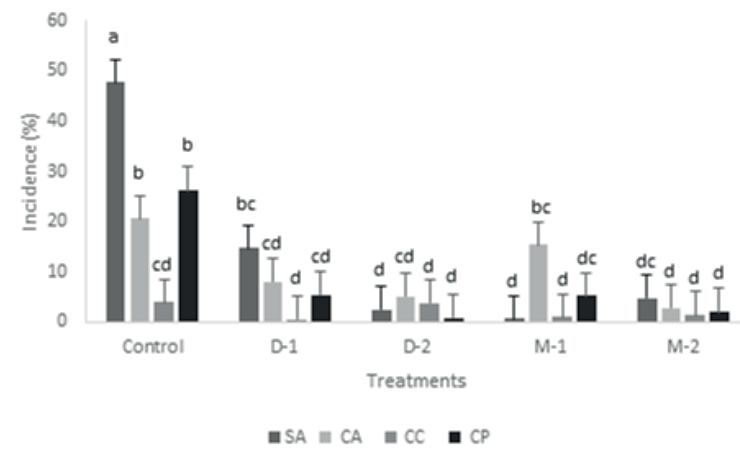

FIGURE 2 Average incidence of damping-off (\%) in $P$. tecunumanii seedlings grown in different substrates and with the application of datura and chamomile extracts in two concentrations: D-I: Datura concentration I, D-2: Datura concentration 2, M-I: Chamomile concentration I, M-2: Chamomile concentration 2, control: no plant extract applied. The average disease incidence was calculated from a total of 75 seedlings per treatment. Different letters denote significant differences among treatments (Tukey test, $\alpha=0.05$ ).

When the $\mathrm{CH}$ substrate was used, none of the extracts significantly decreased the disease incidence $(P>0.05)$. However, it is important to emphasize that when this substrate was used without extract (control), the disease incidence was significantly lower (3.9\%) compared 
to the other three substrates (SSC: $47.7 \%, \mathrm{RHC}: 20.5 \%$ and PBC: $26.2 \%)$, suggesting that the substrate had an effect on the disease incidence by itself (Figure 2).

The interaction of the factors Substrate, Concentration and Time was also found to be significant $(P=<0.000 I)$. In Figure 3 it can be observed that when the $\mathrm{CH}$ substrate was used, none of the extracts had an effect on the disease incidence at any of the times evaluated. After day 14, the controls SSC, RHC and PBC presented the highest incidences compared with all other treatments. At day 19 of evaluation their values were $67 \%, 71.8 \%$ and $47.6 \%$, respectively.

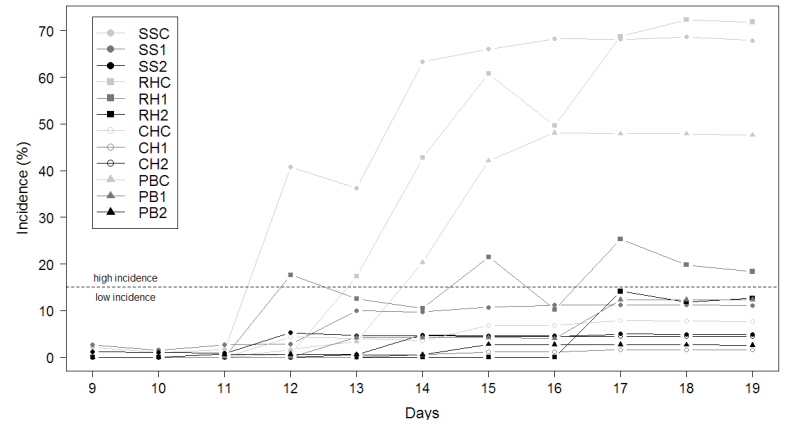

FIGURE 3 Average percentage of disease incidence of damping-off in P. tecunumanii seedlings for the Substrate-Concentration-Time combinations in different growth substrates combined with concentrations of plant extracts. SSC: sandy soil control, SSI: sandy soil concentration I, SS2: sandy soil concentration 2, RHC: rice hull control, $\mathrm{RHI}$ : rice hull concentration I, $\mathrm{RH} 2$ : rice hull concentration 2, CHC: coconut husk control, $\mathrm{CHI}$ : coconut husk concentration I, $\mathrm{CH}$ 2: coconut husk concentration 2 and PBC: pine bark control, $\mathrm{PBI}$ : pine bark concentration I, PB2: pine bark concentration 2. The average percentage of disease incidence was calculated from a total of 75 seedlings per treatment. Significant differences were determined with the Tukey test, with $\alpha=0.05$.

\section{DISCUSSION}

In order to produce $P$. tecunumanii plants, it is necessary to use nursery techniques that promote acceptable rates of germination and survival before the seedlings are transplanted to the field. Damping-off is one of the main causes of seedling loss in nursery. The results obtained in the present study showed that substrates used for growing seedlings had a clear effect on the germination (\%) of $P$. tecunumanii seedlings produced in the nursery under the experimental conditions evaluated. The sandy soil, pine bark and coconut husk substrates favored germination. The rice hull substrate was not favorable to the germination of $P$. tecunumanii seeds. In other studies, an increase in seed germination has been reported for different species of the genus Pinus when using substrates produced with different proportions of forest soil (Rentería et al., 1999).

In terms of controlling the disease, the results showed that different types of substrate in combination with plant extracts applied at different concentrations may decrease the damping-off incidence during the nursery stage. The lowest incidence measured for the controls was found when $\mathrm{CH}$ was used as a substrate. There were no significant differences between this and the treatments exhibiting the lowest disease incidence. This result suggests that the coconut husk substrate discourages disease development by itself. It has been reported that coconut husk contains antimicrobial agents that could have an effect on controlling dampingoff (Sriram et al., 20 I0; Singla et al., 20I I; Verma et al., 2012). Similarly, studies performed on tomato, using coconut substrate to control species of Phytophthora sp. and Fusarium sp., have shown that this substrate enriched with Trichoderma harzianum decreased the disease incidence by $50 \%$ (Sriram et al., 20l0). Another factor that may influence results is the water holding capacity of the substrates. The appropriate humidity percentage in the substrate will induce seed germination without favouring the damping-off disease. Further research is needed to determine the possible mechanism that $\mathrm{CH}$ substrate could have for damping-off control in $P$. tecunumanii seedlings produced under tropical conditions. It has been suggested that coconut substrate could be an acceptable growth medium for producing plants. The use of $\mathrm{CH}$ substrate in forest nurseries may be part of an integrated disease management program. However, additional research is needed about the growth and development of plants during all phases of cultivation.

Other substrates commonly used in the nursery for the production of Pinus seedlings, such as different proportions of soil and pine bark, require the application of control methods such as the plant extracts evaluated in the present study (M. chamomilla and D. stramonium). Additionally, the acquisition of soil to be used as a growth substrate in nursery generates major environmental impacts at the extraction sites, causing erosion and loss of land productivity (Abad et al., 1999). In fact, it has been recommended the importance of replacing materials taken from nature for use as growth media for plants in nursery with alternative substrates such as perlite, coconut fiber, and green compost (De Lucia et al. 20I3).

Some authors have found that rice hulls could be used as a growth medium because they are easy to acquire and have a low weight and cost (Shahidul et al., 2002). However, in the present study this substrate did not 
perform well for controlling damping-off in $P$. tecunumanii seedlings under the conditions evaluated. It also exhibited a particularly poor performance for seed germination.

It was possible to reduce the incidence of disease by using the extract of $\mathrm{M}$. chamomilla in combination with the SS, RH and PB substrates (Figure 2). Jamalian et al. (2012) found 14 compounds in the essential oil of $M$. recutita (without $M$. chamomilla), from which chamazulene was the most abundant (6I.3\%). This compound has recognized antimicrobial properties; in particular, it has shown antifungal effects on dermatophytes, saprophytes and opportunistic fungi. Another study reported that $M$. recutita inhibited the growth of opportunistic saprophytes such as Aspergillus flavus, A. fumigatus, A. niger, Trichoderma harzianum and Fusarium oxysporum (Jamalian et al., 2012).

The $D$. stramonium extract behaved similarly to M. chamomilla when applied to the SS, RH and PB substrates. The use of extract mixtures produced with $D$. stramonium and other plant species has shown antifungal potential against Fusarium mangiferae (USHA et al., 2009). Studies performed with pine bark substrate have shown that this may decrease fungicide applications for controlling damping-off in forest seedlings by inhibiting the pathogens that affect the root (CASTILLO, 2004). These results are in agreement with findings in the present study, when comparing PB and SS. Our results are similar to those that indicate that the use of plant extracts obtained from Calotropis procera, Nerium oleander, Eugenia jambolana, Citrullus colocynthis, Acacia nilotica and Ocimum basilicum, may significantly decrease damping-off in seedlings of diverse species produced under nursery conditions (Abdel-Monaim et al., 20l I).

Further research is needed to determine if the combination of different substrate may have a synergistic effect when compared to their individual use. Plant extracts showed disease incidence reduction in combination with the substrates, therefore it is desirable to continue testing different sources and combinations with plant extracts.

\section{CONCLUSION}

To summarize, our findings made it possible to determine the effectiveness of alternative techniques for controlling damping-off of $P$. tecunumanii in the nursery, based on the use of growth substrates and plant extracts. The Coconut Husk substrate was found to be of particular interest in controlling the disease, because it was able to significantly decrease its incidence even without the application of plant extracts as control products. Other substrates commonly used in nursery for the production of seedlings of the genus Pinus, such as Sandy Soil and Pine Bark, should be accompanied by the application of plant extracts like those evaluated in the present study (M. chamomilla and D. stramonium). Given that obtaining soil for use as a nursery growth substrate generates major environmental impacts at the extraction sites, it is important to use alternative substrates for nursery production, such as those mentioned. On the other hand, although the Rice Hull substrate is easy to obtain, it did not show satisfactory effects on germination or disease incidence reduction in $P$. tecunumanii seedlings.

\section{REFERENCES}

ABAD, M.; NOGUERA, P.; NOGUERA, V.; and SEGURA, M. L. Los sustratos para el semillero hortícola. Planteles, Compendios de Horticultura, n. 13, p. 59-68, 1999.

ABDEL-MONAIM, M. F.; ABO-ELYOUSR, K. A. M.; MORSY, K. M. Effectiveness of plant extracts on suppression of damping-off and wilt diseases of lupine (Lupinus termis Forsik). Crop protection, v. 30, n. 2, p. I85-19I, 201 I.

BENÍTEZ, G.; EQUIHUA, M.; PULIDO-SALAS, M. T. Diagnóstico de la situación de los viveros oficiales de Veracruz y su papel para apoyar programas de reforestación y restauración. Revista Serie Ciencias Forestales y del Ambiente, v. 8, n I, p. 5-12, 2002.

CAMPOROTA, P.; PERRIN, R. Characterization of Rhizoctonia species involved in tree seedling damping-off in French forest nurseries. Applied Soil Ecology, v. 10, n. I, p. 657I, 1998.

CASTILLO, J. V. Inoculating composted pine bark with beneficial organisms to make a disease suppressive compost for container production in Mexican forest nurseries. Native Plants Journal, v. 5, n. 2, p. I8I-I85, 2004.

DE LUCIA, B.; CRISTIANO, G.; VECCHIETTI, L.; REA, E.; and RUSSO, G. Nursery growing media: agronomic and environmental quality assessment of sewage sludge-based compost. Applied and Environmental Soil Science, v.2013, p. I-10, 2013.

FAJARDO-MEJÍA, A.; JAIMES, E. P. G.; and CASTAÑO, $H$. I. Estudio de extractos vegetales en la inhibición de la liberación de zoosporas de Spongospora subterranea $f$. sp. subterranea. Revista Politécnica, v.9, n. 17, p. I13-121, 2013.

FAJARDO-MEJÍA, A; LEÓN, J. D.; MORALES, J. G.; CORREA, G.; and OSORIO, N. W. Isolation and pathogenicity off Fusarium sp. obtained from Pinus tecunumanii seedlings. Revista de la Asociación Colombiana de la Fitopatología y Ciencias Afines ASCOLFI, v.39, n.I Suplemento.19, p.36, 2015. 
GORDON, T. R.; SWETT, C. L.; and WINGFIELD, M. J. Management of Fusarium diseases affecting conifers. Crop Protection, v.73, p. 28-39, 2015.

JAMALIAN, A.; SHAMS-GHAHFAROKHI, M.; JAIMAND, K.; PASHOOTAN, N.; AMANI, A.; and RAZZAGHIABYANEH, M. Chemical composition and antifungal activity of Matricaria recutita flower essential oil against medically important dermatophytes and soil-borne pathogens. Journal of Medical Mycology, v. 22, n. 4, p. 308-3I5, 2012.

KACPRZAK, M.; ASIEGBU, F. O.; DANIEL, G., STENLID, J.; MANKA, M.; and JOHANSSON, M. Resistance reaction of conifer species European larch, Norway spruce, Scots pine to infection by selected necrotrophic damping-off pathogens. European Journal of Plant Pathology, v. I07, n. 2, p. |9|-207.

LANDIS, T. D.; and MORGAN, N. Growing media alternatives for forest and native plant nurseries. Dumroese, RK; LE Riley. National Proceedings: Forest and Conservation Nursery Associations. US Department of Agriculture, Forest Service, Rocky Mountain Research Station, p. 26-3I, 2009.

MACHÓN, P.; PAJARES, J. A.; DIEZ, J. J.; and ALVES-SANTOS, F. $M$. Influence of the ectomycorrhizal fungus Laccaria laccata on pre-emergence, post-emergence and late damping-off by Fusarium oxysporum and $F$. verticillioides on Stone pine seedlings. Symbiosis, v.49, n. 2, p. 101-109,2009.

MARCANO, D.; and HASEGAWA,M. Fitoquímica Orgánica. Universidad Central de Venezuela. Caracas, Venezuela. V. 2002, p. 487-588, 2002.

MARTÍN-PINTO, P.; PAJARES, J.; and DÍEZ, J. In vitro effects of four ectomycorrhizal fungi, Boletus edulis, Rhizopogon roseolus, Laccaria laccata and Lactarius deliciosus on Fusarium damping-off in Pinus nigra seedlings. New Forests, v.32, n. 3, p. 323-334,2006.

PROEXPORT Colombia. Sector Forestal en colombia, 16. Retrieved from http://www.botschaftkolumbien.de/ descargas_proexport/berlin_20II/espanol/inversion/ agroindustria/perfil_forestal.pdf,2010.

Rauf, B. A. Seed-borne disease problems of legume crops in Pakistan.Pakistan Journal of Scientific and Industrial Research. v.43, n.4, p. 249-254.
RENTERÍA, A. A.; JIMÉNEZ, H. C.; and LANDA, J. A. Pinus montezumae Lamb. Y Pinus pseudostrobus Lindl. en condiciones de vivero. Foresta Veracruzana. v. I, n. 2, p 3I-34, 1999.

SÁEZ, J. N. P. Utilización de sustratos en viveros. Terra. v. 17, n.3, p. $231-235,1999$.

SHAHIDUL ISLAM, M.; KHAN, S.; ITO, T.; MARUO, T.; and SHINOHARA, Y. Characterization of the physico-chemical properties of environmentally friendly organic substrates in relation to rockwool. Journal of Horticultural Science and Biotechnology, v. 77, n. 2, p. |43-|48, 2002.

SRIRAM, S.; SAVITHA, M. J.; and RAMANUJAM, B. Trichoderma-enriched coco-peat for the management of Phytophthora and Fusarium diseases of chilli and tomato in nurseries. Journal of Biological Control, v. 24, n. 4 , p. $311-316,2010$.

SINGLA R. K.; JAISWAL N.; BHAT V. G.; and JAGANI H. Antioxidant and Antimicrobial Activities of Cocos Nucifera Linn. (Arecaceae) Endocarp Extracts. Indo Global Journal of Pharmaceutical Sciences, v. I, n. 4, p. 354-36I, 20 I I.

SOLDEVILLA, C. Marras de origen fúngico Damping-off en plantas del género Pinus sp . Cultivadas en invernadero. Boletín de Sanidad Vegetal, v. 21, n. I, p. 87-109, 1995.

TOLOUEE, M.; ALINEZHAD, S.; SABERI, R.; ESLAMIFAR, A.; ZAD, S. J.; JAIMAND, K.; and RAZZAGHI-ABYANEH, M. Effect of Matricaria chamomilla L. flower essential oil on the growth and ultrastructure of Aspergillus niger van Tieghem. International Journal of Food Microbiology, v. I 39, n.3, p. I27-I33, 2010.

TORRES, D.; and CAPOTE, T. Agroquímicos un problema ambiental global: uso del análisis químico como herramienta para el monitoreo ambiental. Revista Ecosistemas, v.13, n. 3, p.2-6, 2004.

USHA, K.; SINGH, B.; PRASEETHA, P.; DEEPA, N.; AGARWAL, D. K.; AGARWAL, R.; and NAGARAJA, A. Antifungal activity of Datura stramonium, Calotropis gigantea and Azadirachta indica against Fusarium mangiferae and floral malformation in mango. European Journal of Plant Pathology, v. I 24, n.4, p. 637-657,2009.

UPRAColombia.,http://www.upra.gov.co/publicaciones// asset_publisher/iYsfmyAWxSAr/content/zonificacion-paraplantaciones-forestales-con-fines-comerciales colombiaescala-I I00-000

VERMA V.; BHARDWAJ A.; RATHI S.; and RAJA R.B. A Potential Antimicrobial Agent from Cocos nucifera mesocarp extract; Development of a New Generation Antibiotic. ISCA Journal of Biological Sciences, v. I, n. 2, p. 48-54, 2012. 
